\title{
Microbacterium ginsengiterrae sp. nov., a $\beta$-glucosidase-producing bacterium isolated from soil of a ginseng field
}

\author{
Correspondence \\ Deok-Chun Yang \\ deokchunyang@yahoo.co.kr
}

\author{
Yeon-Ju Kim, Myung Kyum Kim, Thi Phuong Nam Bui, Ho-Bin Kim, \\ Sathiyaraj Srinivasan and Deok-Chun Yang
}

Korean Ginseng Center and Ginseng Genetic Resource Bank, Kyung Hee University, 1 Seocheondong, Giheung-gu Yongin-si, Gyeonggi-do 449-701, Republic of Korea

\begin{abstract}
Strain DCY $37^{\top}$ was isolated from a soil sample of a ginseng field in the Republic of Korea and characterized in order to determine its taxonomic position. Cells were Gram-staining-positive, heterotrophic, strictly aerobic, non-motile short rods. 16S rRNA gene sequence analysis revealed that strain DCY $37^{\top}$ belongs to the genus Microbacterium. According to $16 \mathrm{~S}$ rRNA gene sequence analysis, it is closely related to Microbacterium aerolatum DSM $14217^{\top}$ (98.8\%), Microbacterium hydrocarbonoxydans DSM $16089^{\top}$ (98.5\%), Microbacterium natoriense JCM $12611^{\top}$ (98.5\%), Microbacterium foliorum (98.4\%) and Microbacterium phyllosphaerae (98.3\%). However, DNA-DNA hybridization studies showed reassociation values of less than $70 \%$ between representative strains and DCY $37^{\top}$. The DNA G $+C$ content was $64.5 \mathrm{~mol} \%$. Strain DCY $37^{\top}$ possessed chemotaxonomic markers that were consistent with classification in the genus Microbacterium, i.e. MK-12 and MK-13 as the major menaquinones and anteiso- $\mathrm{C}_{15: 0}$, anteiso- $\mathrm{C}_{17: 0}$ and iso- $\mathrm{C}_{16: 0}$ as the predominant cellular fatty acids. The major cell wall sugars were ribose, xylose and galactose. The diamino acid in cell-wall hydrolysates of strain DCY $37^{\top}$ was ornithine and major cell-wall amino acids were alanine, glycine, D-glutamic acid and serine. The major polar lipids were glycolipid, phosphatidylglycerol, diphosphatidylglycerol and unknown

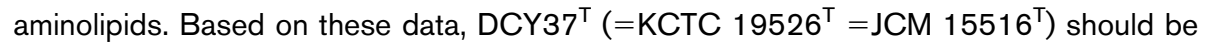
classified as the type strain of a novel species of the genus Microbacterium, for which the name Microbacterium ginsengiterrae sp. nov. is proposed.
\end{abstract}

Members of the genus Microbacterium can be isolated from a wide range of different environmental habitats from soil to insects, human clinical specimens and marine environments. The genus Microbacterium (phylum Actinobacteria, class Actinobacteria, order Actinomycetales, family Microbacteriaceae) was first reported by Orla-Jensen and was emended by Collins et al.. More recently, the genus was emended again to unite the genera Microbacterium and Aureobacterium. At the time of writing, the genus Microbacterium consisted of 68 species with validly published names, including three species (Microbacterium soli, Microbacterium azadirachtae and Microbacterium agarici) whose descriptions were still in press. In this study, we characterized a new isolate belonging to the genus Microbacterium. Extensive physiological, chemotaxonomic and phylogenetic analyses were

The GenBank/EMBL/DBBJ accession number for $16 \mathrm{~S}$ rRNA gene sequence of strain DCY37 ${ }^{\top}$ is EU873314.1.

A transmission electron micrograph of cells of strain $\mathrm{DCY} 37^{\top}$, and polar lipid and fatty acid profiles of strain $\mathrm{DCY} 37^{\top}$, are available with the online version of this paper. carried out to determine the precise taxonomic position of strain DCY $37^{\mathrm{T}}$.

Cell morphology and motility were observed with a Nikon light microscope ( $\times 1000$ magnification) using the hanging drop method, with cells grown on R2A agar for 2 days at $30{ }^{\circ} \mathrm{C}$. Transmission electron microscopy was carried out as follows. Bacteria were grown on R2A plates at $30{ }^{\circ} \mathrm{C}$ for $24 \mathrm{~h}$. Resuspended cells were placed on carbon- and Formvar-coated nickel grids for $30 \mathrm{~s}$. Grids were floated on one drop of $0.1 \%(\mathrm{w} / \mathrm{v})$ aqueous uranyl acetate and then viewed with a Carl Zeiss LEO912AB electron microscope at $100 \mathrm{kV}$ under standard operating conditions.

The Gram reaction was performed according to the nonstaining method (Buck, 1982). Oxidase activity was evaluated via the oxidation of $1 \% p$-aminodimethylaniline oxalate. Catalase activity was revealed by bubble production after the application of $3 \%(\mathrm{v} / \mathrm{v})$ hydrogen peroxide solution. Growth on nutrient agar (NA), trypticase soy agar (TSA), R2A agar, LB agar and MacConkey agar was evaluated at $30{ }^{\circ} \mathrm{C}$. Growth at different temperatures $(4,18$, $25,30,37$ and $42{ }^{\circ} \mathrm{C}$ ) and various $\mathrm{pH}$ (5.0-10.0 at intervals 
of $0.5 \mathrm{pH}$ units) was assessed after 5 days of incubation on R2A plates. Salt tolerance was tested in R2 broth supplemented with $0-10 \%(\mathrm{w} / \mathrm{v}) \mathrm{NaCl}$ after 5 days of incubation. Strain $\mathrm{DCY} 37^{\mathrm{T}}$ and the type strains Microbacterium hydrocarbonoxydans DSM $16089^{\mathrm{T}}$, Microbacterium natoriense
JCM $12611^{\mathrm{T}}$, Microbacterium aerolatum DSM $14217^{\mathrm{T}}$ and Microbacterium foliorum DSM $12966^{\mathrm{T}}$ were grown on TSA for 2 days at $30{ }^{\circ} \mathrm{C}$ for fatty acid analysis. The API 20NE, API ZYM and API ID32 GN microtest systems were employed following the recommendations of the manufacturer

Table 1. Phenotypic characteristics differentiating strain $\mathrm{DCY} 37^{\top}$ and related type strains of species of the genus Microbacterium

Taxa: 1, Microbacterium ginsengiterrae sp. nov. DCY $37^{\mathrm{T}} ; 2$, M. hydrocarbonoxydans DSM $16089^{\mathrm{T}} ; 3$, Microbacterium natoriense JCM $12611^{\mathrm{T}}$; 4, Microbacterium aerolatum DSM $14217^{\mathrm{T}} ; 5$, Microbacterium foliorum DSM $12966^{\mathrm{T}}$. Data from this study, except where indicated. All five strains were positive for activities of esterase (C4), esterase lipase (C8), arginine dihydrolase, urease, $\alpha$-glucosidase, $\beta$-glucosidase and assimilation of sucrose. All five strains were negative for the reduction of nitrates to nitrites, indole production, alkaline phosphatase, valine arylamidase, cystine arylamidase, trypsin and $\alpha$-fucosidase activities, assimilation of suberic acid, sodium malonate, potassium 5-ketogluconate, L-fucose, D-sorbitol, capric acid, adipate and phenylacetate, and for gelatin hydrolysis. +, Positive; -, negative; W, weakly positive; ND, no data available; PY, pale yellow; Y, yellow; DY, deep yellow.

\begin{tabular}{|c|c|c|c|c|c|}
\hline Characteristic & 1 & 2 & 3 & 4 & 5 \\
\hline Colour of colonies & PY & $\mathrm{Y}$ & PY & $\mathrm{Y}$ & DY \\
\hline Growth at $6 \% \mathrm{NaCl}$ & + & + & - & + & - \\
\hline Lipase (C14) & - & - & $\mathrm{w}$ & $\mathrm{w}$ & - \\
\hline Leucine arylamidase & - & - & + & + & - \\
\hline$\alpha$-Chymotrypsin & - & - & + & - & - \\
\hline Naphthol-AS-BI-phosphohydrolase & + & - & - & - & - \\
\hline$\beta$-Galactosidase & - & $\mathrm{w}$ & + & - & + \\
\hline$\beta$-Glucuronidase & - & - & - & - & $\mathrm{w}$ \\
\hline$\alpha$-Mannosidase & + & + & + & - & - \\
\hline \multicolumn{6}{|l|}{ Assimilation of (API $20 \mathrm{NE}$ ): } \\
\hline Glucose & - & + & + & - & - \\
\hline Maltose & - & + & + & - & $\mathrm{w}$ \\
\hline Gluconate & - & + & + & - & $\mathrm{w}$ \\
\hline Malate & - & + & + & - & - \\
\hline Trisodium citrate & - & + & + & $\mathrm{w}$ & $\mathrm{w}$ \\
\hline \multicolumn{6}{|l|}{ Assimilation of (API $32 \mathrm{GN}$ ): } \\
\hline L-Rhamnose & $\mathrm{w}$ & + & - & - & - \\
\hline D-Ribose & + & - & - & - & - \\
\hline Inositol & - & - & + & - & - \\
\hline Itaconic acid & - & - & - & $\mathrm{w}$ & - \\
\hline Sodium acetate & - & $\mathrm{w}$ & + & - & - \\
\hline Lactic acid & - & $\mathrm{w}$ & - & - & - \\
\hline Potassium 2-ketogluconate & + & $\mathrm{w}$ & - & w & W \\
\hline Major menaquinones (MK) & 12,13 & $11,12^{a}$ & $9,10,11,12^{b}$ & $11,12,13^{c}$ & $10,11,12^{d}$ \\
\hline DNA G $+C$ content $(\mathrm{mol} \%)$ & 64.5 & ND & $69.1^{b}$ & $68.1^{c}$ & $67^{d}$ \\
\hline
\end{tabular}

${ }^{\star}$ Data from: $a$, Schippers et al. (2005); b, Liu et al. (2005); c, Zlamala et al. (2002); d, Behrendt et al. (2001). 
(bioMérieux). The API kits were incubated at $30{ }^{\circ} \mathrm{C}$ and results were checked after $24 \mathrm{~h}$ and $48 \mathrm{~h}$, except for API ZYM where results were recorded after $10 \mathrm{~h}$. Cells grown in LB for 6 days at $26{ }^{\circ} \mathrm{C}$ were used for determination of the respiratory quinone system. Differential phenotypic characteristics between strain $\mathrm{DCY} 37^{\mathrm{T}}$ and the most closely related type strains of species of the genus Microbacterium are summarized in Table 1.

Isoprenoid quinones were extracted with chloroform/ methanol $(2: 1, \mathrm{v} / \mathrm{v})$, purified by TLC and subsequently analysed by HPLC, as described by Collins \& Jones (1981) and Shin et al. (1996). For fatty acid analysis, strain $\mathrm{DCY} 37^{\mathrm{T}}$ and the other type strains $(M$. hydrocarbonoxydans DSM $16089^{\mathrm{T}}, M$. natoriense JCM $12611^{\mathrm{T}}$, M. aerolatum DSM $14217^{\mathrm{T}}$ and M. foliorum DSM $12966^{\mathrm{T}}$ ) were grown on TSA for $48 \mathrm{~h}$ at $30{ }^{\circ} \mathrm{C}$, and $50 \mathrm{mg}$ of the biomass was harvested. Fatty acid methyl esters were prepared, separated and identified with the Sherlock Microbial Identification System (MIDI; Sasser, 1990).

Polar lipids were extracted and examined by twodimensional TLC (Minnikin et al., 1977; Bligh \& Dyer, 1959). Amino-acid composition in the cell wall peptidoglycan was determined by using TLC after hydrolysis with $6 \mathrm{M} \mathrm{HCl}$ at $100{ }^{\circ} \mathrm{C}$ for $18 \mathrm{~h}$ (Busse et al., 1996; Schenkel et al., 1995; Komagata \& Suzuki, 1987). Cell wall sugars were analysed as described by Staneck \& Roberts (1974).

Genomic DNA of the novel strain was extracted and purified, degraded by P1 nuclease into nucleosides, and the $\mathrm{G}+\mathrm{C}$ content was determined as described by Mesbah et al. (1989) using reversed-phase HPLC.

DNA-DNA hybridization was carried out with photobiotin-labelled probes in microplate wells as described by Ezaki et al. (1989), using a BioAssay reader for fluorescence measurement. The hybridization temperature was $37^{\circ} \mathrm{C}$. Five replications were performed for each sample; the highest and lowest values were excluded and the remaining three values were used for calculation of hybridization values. Reciprocal experiments were performed.

Genomic DNA of strain DCY $37^{\mathrm{T}}$ was extracted and purified by using a Genomic DNA Isolation kit (Core Bio System). The 16S rRNA gene was amplified and sequenced by using the universal bacterial primer sets $9 \mathrm{~F}$ and $1512 \mathrm{R}$, and $27 \mathrm{~F}$ and 1492R, respectively (Kim et al., 2005). The purified PCR products were sequenced by Genotec, Daejeon, Korea. $16 \mathrm{~S}$ rRNA gene sequences were compiled by using SeqMan software, and edited using the BioEdit program (Hall, 1999). Multiple alignments were performed with the CLUSTAL $\mathrm{X}$ program (Thompson et al., 1997), and the Kimura twoparameter model (Kimura, 1983) was used to calculate evolutionary distances. Neighbour-joining (Saitou \& Nei, 1987) and maximum-parsimony trees were reconstructed using the MEGA 3 (Felsenstein, 1985) and PHYLIP programs (Choi et al., 2000), respectively.

Strain DCY $37^{\mathrm{T}}$ was an aerobic, Gram-positive, rod-shaped $(0.5-0.7 \mu \mathrm{m}$ in diameter and $1.5-2.0 \mu \mathrm{m}$ in length;
Supplementary Fig. S1, available in IJSEM online) and non-motile bacterium. Colonies on R2A agar were pale yellow, circular and slightly convex after 3 days of cultivation at $30{ }^{\circ} \mathrm{C}$. Growth occurred between 15 and $45{ }^{\circ} \mathrm{C}$ and at pH 5 to 9; optimal growth occurred at $30{ }^{\circ} \mathrm{C}$ and $\mathrm{pH}$ 7.0. Poor growth was observed in the absence of $\mathrm{NaCl}$ and in the presence of $>8 \%(\mathrm{w} / \mathrm{v}) \mathrm{NaCl}$. The strain was slightly halophilic. The physiological characteristics of strain $\mathrm{DCY} 37^{\mathrm{T}}$ are summarized in the species description and a comparison of selected characteristics with those of related type strains is shown in Table 1.

The main fatty acids detected in strain $\mathrm{DCY} 37^{\mathrm{T}}$ were anteiso- $\mathrm{C}_{15: 0}(44.9 \%)$, anteiso- $\mathrm{C}_{17: 0}(30.6 \%)$ and iso$\mathrm{C}_{16: 0}(11.2 \%)$ (Supplementary Table S1). The major menaquinones detected for this strain were MK-12 and MK-13. This pattern has been reported for other species of the genus Microbacterium (Schippers et al., 2005). The major polar lipids were glycolipid, phosphatidylglycerol, diphosphatidylglycerol and unknown aminolipids. The genus Microbacterium (and Aureobacterium) is characterized by diphosphatidylglycerol, phosphatidylglycerol and an unusual glycolipid, and these have been detected as the major polar lipids in numerous species of the genus (Young et al., 2010). The major cell-wall sugars were ribose, xylose and galactose. The diamino acid in cell-wall hydrolysates of strain $\mathrm{DCY} 37^{\mathrm{T}}$ was ornithine. The major cell-wall amino acids were alanine, glycine, D-glutamic acid and serine. Analytical data suggested the presence of peptidoglycan type B2 $\beta$ in strain DCY $37^{\mathrm{T}}$.

The 16S rRNA gene sequence of strain $\mathrm{DCY} 37^{\mathrm{T}}$, a continuous stretch of $1427 \mathrm{nt}$, was sequenced. The phylogenetic tree shows that strain DCY $37^{\mathrm{T}}$ was clustered within the genus Microbacterium of the class Actinobacteria. It is closely related to M. aerolatum DSM $14217^{\mathrm{T}}(98.8 \%)$, M. hydrocarbonoxydans DSM $16089^{\mathrm{T}}(98.5 \%)$, M. natoriense JCM $12611^{\mathrm{T}}(98.5 \%)$, M. foliorum DSM $12966^{\mathrm{T}}$ $(98.4 \%)$ and Microbacterium phyllosphaerae DSM $13468^{\mathrm{T}}$ (98.3\%) (Fig. 1). The DNA G+C content of strain DCY $37^{\mathrm{T}}$ was $64.5 \mathrm{~mol} \%$, a value within the range reported for members of the genus Microbacterium (Table 1). However, the DNA-DNA relatedness values between strain DCY $37^{\mathrm{T}}$ and strains $M$. aerolatum DSM $14217^{\mathrm{T}}, M$. hydrocarbonoxydans DSM $16089^{\mathrm{T}}$, M. natoriense JCM $12611^{\mathrm{T}}$ and M. foliorum DSM $12966^{\mathrm{T}}$ were $51.8 \pm 0.7$, $41.8 \pm 0.4, \quad 35.4 \pm 0.8$ and $29.8 \pm 0.3 \%$, respectively. Reciprocal hybridization tests resulted in DNA-DNA relatedness values of $37.7 \%$ between $M$. hydrocarbonox$y$ dans DSM $16089^{\mathrm{T}}$ and strain DCY $37^{\mathrm{T}}$. These results show that strain $D C Y 37^{\mathrm{T}}$ is an independent species at the genotype level according to the limits devised by Wayne et al. (1987).

Based on the phylogenetic analysis and phenotypic characteristics, strain DCY $37^{\mathrm{T}}$ is described as a novel species in the genus Microbacterium, for which the name Microbacterium ginsengiterrae sp. nov. (type strain DCY $37^{\mathrm{T}}$ $=$ KCTC $19526^{\mathrm{T}}=\mathrm{JCM} 15516^{\mathrm{T}}$ ) is proposed. 


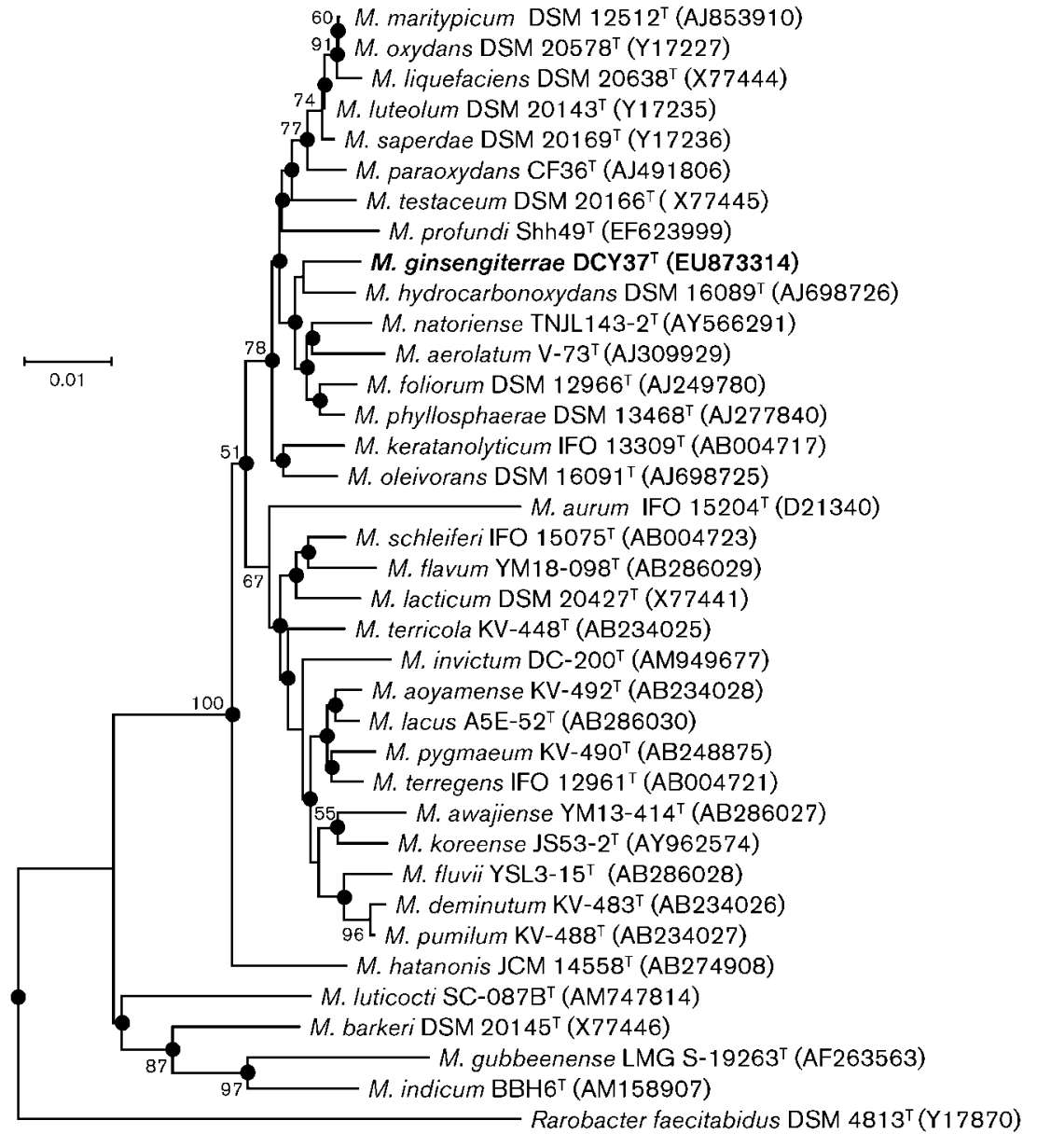

Fig. 1. Neighbour-joining tree, based on 16S rRNA gene sequences, showing the phylogenetic relationships of strain $\mathrm{DCY} 37^{\top}$ and representative members of the genus Microbacterium. Rarobacter faecitabidus DSM $4813^{\top}$ was used as an outgroup. Bootstrap values $>50 \%$ based on 1000 replications are shown at branching points. Filled circles indicate that the corresponding nodes were also recovered in the tree generated using the maximum-parsimony algorithm. Bar, 0.01 substitutions per nucleotide position.

\section{Description of Microbacterium ginsengiterrae sp. nov.}

Microbacterium ginsengiterrae (gin.seng.i.ter'rae. N.L. n. ginsengum ginseng; L. n. terra soil; N.L. gen. n. ginsengiterrae of soil of a ginseng field, the source of the type strain).

Cells are Gram-positive, heterotrophic, strictly aerobic, non-motile and rod-shaped $(0.5-0.7 \mu \mathrm{m}$ diameter and 1.5$2.0 \mu \mathrm{m}$ length). Colonies on R2A agar are circular with regular edges, yellow and translucent with a diameter of 2 $3 \mathrm{~mm}$ after 2 days of incubation on R2A agar. Grows between 15 and $45^{\circ} \mathrm{C}$ and at $\mathrm{pH} 5$ to 9 . Optimal growth at $30{ }^{\circ} \mathrm{C}$ and $\mathrm{pH}$ 7.0. Poor growth in the absence of $\mathrm{NaCl}$ and in the presence of $>8 \%(\mathrm{w} / \mathrm{v}) \mathrm{NaCl}$. Slightly halophilic. Catalase, oxidase and DNase activities are present. In the API ZYM kit, $\alpha$-glucosidase, $\beta$-glucosidase, esterase (C4), esterase lipase (C8), naphthol-AS-BI-phosphohydrolase and $\alpha$-mannosidase activities are present; alkaline phosphatase, lipase (C14), leucine arylamidase, valine arylamidase, cystine arylamidase, trypsin, $\alpha$-chymotrypsin, acid phosphatase, $\alpha$-galactosidase, $\beta$-galactosidase, $\beta$-glucuronidase, $N$-acetyl- $\beta$-glucosaminidase and $\alpha$-fucosidase activities are absent. In the API 20NE kit, arginine dihydrolase and urease reactions are positive; the following reactions are negative: reduction of nitrate to nitrite, reduction of nitrate to nitrogen, indole production, protease, $\beta$ galactosidase, glucose acidification, and assimilation of L-arabinose, D-mannitol, $\mathrm{N}$-acetylglucosamine, maltose, potassium gluconate, capric acid, adipic acid, malic acid, trisodium citrate and phenylacetic acid. In the API 32GN kit, the following substrates are assimilated: D-ribose, Lrhamnose, sucrose, 3-hydroxybenzoic acid and 4-hydroxybenzoic acid; the following substrates are not assimilated: glucose, inositol, itaconic acid, suberic acid, sodium malonate, sodium acetate, L-alanine, glycogen, L-serine, salicin, melibiose, L-fucose, D-sorbitol, propionic acid, capric acid, valeric acid, L-histidine, 3-hydroxybutyric acid and L-proline. The predominant menaquinones are MK-12 and $\mathrm{MK}-13$. The major fatty acids are anteiso- $\mathrm{C}_{15: 0}$, anteiso- $\mathrm{C}_{17: 0}$ and iso- $\mathrm{C}_{16: 0}$. The major cell-wall sugars are ribose, xylose and galactose. The cell-wall peptidoglycan is of the B2 $\beta$ type, (L-Hsr) $-\mathrm{D}-\mathrm{Glu} \rightarrow \mathrm{Gly} \rightarrow \mathrm{D}-\mathrm{Orn}$. The major polar lipids are glycolipid, phosphatidylglycerol, diphosphatidylglycerol and unknown aminolipids. The DNA $\mathrm{G}+\mathrm{C}$ content of the type strain is $64.5 \mathrm{~mol} \%$.

The type strain, DCY $37^{\mathrm{T}}\left(=\right.$ KCTC $\left.19526^{\mathrm{T}}=\mathrm{JCM} 15516^{\mathrm{T}}\right)$, was isolated from soil of a ginseng field in the Republic of Korea. 


\section{Acknowledgements}

This work was supported by a grant from the Plant Diversity Research Center of the 21st Century Frontier Research Program (code no. PF06222-00) funded by the Ministry of Science and Technology of the Korean government.

\section{References}

Behrendt, U., Ulrich, A. \& Schumann, P. (2001). Description of Microbacterium foliorum sp. nov. and Microbacterium phyllosphaerae sp. nov., isolated from the phyllosphere of grasses and the surface litter after mulching the sward, and reclassification of Aureobacterium resistens (Funke et al. 1998) as Microbacterium resistens comb. nov. Int J Syst Evol Microbiol 51, 1267-1276.

Bligh, E. G. \& Dyer, W. J. (1959). A rapid method of total lipid extraction and purification. Can J Biochem Physiol 37, 911-917.

Buck, J. D. (1982). Nonstaining ( $\mathrm{KOH})$ method for determination of Gram reactions of marine bacteria. Appl Environ Microbiol 44, 992993.

Busse, H.-J., Denner, E. B. M. \& Lubitz, W. (1996). Classification and identification of bacteria: current approaches to an old problem. Overview of methods used in bacterial systematics. J Biotechnol 47, 3-38.

Choi, J.-H., Jung, H.-Y., Kim, H.-S. \& Cho, H.-G. (2000). PhyloDraw: a phylogenetic tree drawing system. Bioinformatics 16, 1056-1058.

Collins, M. D. \& Jones, D. (1981). Distribution of isoprenoid quinone structural types in bacteria and their taxonomic implication. Microbiol Rev 45, 316-354.

Ezaki, T., Hashimoto, Y. \& Yabuuchi, E. (1989). Fluorometric deoxyribonucleic acid-deoxyribonucleic acid hybridization in microdilution wells as an alternative to membrane filter hybridization in which radioisotopes are used to determine genetic relatedness among bacterial strains. Int J Syst Bacteriol 39, 224-229.

Felsenstein, J. (1985). Confidence limits on phylogenies: an approach using the bootstrap. Evolution 39, 783-791.

Hall, T. A. (1999). BioEdit: a user-friendly biological sequence alignment editor and analysis program for Windows 95/98/NT. Nucleic Acids Symp Ser 41, 95-98.

Kim, M. K., Im, W.-T., Ohta, H., Lee, M. \& Lee, S.-T. (2005). Sphingopyxis granuli sp. nov., a $\beta$-glucosidase-producing bacterium in the family Sphingomonadaceae in $\alpha-4$ subclass of the Proteobacteria. J Microbiol 43, 152-157.

Kimura, M. (1983). The Neutral Theory of Molecular Evolution. Cambridge: Cambridge University Press.

Komagata, K. \& Suzuki, K. (1987). Lipid and cell-wall analysis in bacterial systematics. Methods Microbiol 19, 161-207.

Liu, J., Nakayama, T., Hemmi, H., Asano, Y., Tsuruoka, N., Shimomur, K., Nishijima, M. \& Nishino, T. (2005). Microbacterium natoriense sp. nov., a novel D-aminoacylase-producing bacterium isolated from soil in Natori, Japan. Int J Syst Evol Microbiol 55, 661665.

Mesbah, M., Premachandran, U. \& Whitman, W. B. (1989). Precise measurement of the $\mathrm{G}+\mathrm{C}$ content of deoxyribonucleic acid by high-performance liquid chromatography. Int J Syst Bacteriol 39, 159167.

Minnikin, D. E., Patel, P. V., Alshamaony, L. \& Goodfellow, M. (1977). Polar lipid composition in the classification of Nocardia and related bacteria. Int J Syst Bacteriol 27, 104-117.

Saitou, N. \& Nei, M. (1987). The neighbor-joining method: a new method for reconstructing phylogenetic trees. Mol Biol Evol 4, 406425.

Sasser, M. (1990). Identification of bacteria by gas chromatography of cellular fatty acids, MIDI Technical Note 101. Newark, DE: MIDI Inc.

Schenkel, E., Berlaimont, V., Dubois, J., Helson-Cambier, M. \& Hanocq, M. (1995). Improved high-performance liquid chromatographic method for the determination of polyamines as their benzoylated derivatives: application to P388 cancer cells. J Chromatogr B Biomed Appl 668, 189-197.

Schippers, A., Bosecker, K., Spröer, C. \& Schumann, P. (2005). Microbacterium oleivorans sp. nov., and Microbacterium hydrocarbonoxydans sp. nov., novel crude-oil-degrading Gram-positive bacteria. Int J Syst Evol Microbiol 55, 655-660.

Shin, Y. K., Lee, J.-S., Chun, C. O., Kim, H.-J. \& Park, Y.-H. (1996). Isoprenoid quinone profiles of the Leclercia adecarboxylata KCTC $1036^{\mathrm{T}}$. J Microbiol Biotechnol 6, 68-69.

Staneck, J. L. \& Roberts, G. D. (1974). Simplified approach to identification of aerobic actinomycetes by thin-layer chromatography. Appl Microbiol 28, 226-231.

Thompson, J. D., Gibson, T. J., Plewniak, F., Jeanmougin, F. \& Higgins, D. G. (1997). The CLUSTAL_X windows interface: flexible strategies for multiple sequence alignment aided by quality analysis tools. Nucleic Acids Res 25, 4876-4882.

Wayne, L. G., Brenner, D. J., Colwell, R. R., Grimont, P. A. D., Kandler, O., Krichevsky, M. I., Moore, L. H., Moore, W. E. C., Murray, R. G. E. \& other authors (1987). International Committee on Systematic Bacteriology. Report of the ad hoc committee on reconciliation of approaches to bacterial systematics. Int J Syst Bacteriol 37, 463-464.

Young, C.-C., Busse, H.-J., Langer, S., Chu, J.-N., Schumann, P., Arun, A. B., Shen, F.-T., Rekha, P. D. \& Kämpfer, P. (2010). Microbacterium agarici sp. nov., Microbacterium humi sp. nov., and Microbacterium pseudoresistens sp. nov., isolated from the base of the mushroom Agaricus blazei. Int J Syst Evol Microbiol 60, 854-860.

Zlamala, C., Schumann, P., Kämpfer, P., Valens, M., Rosselló-Mora, R., Lubitz, W. \& Busse, H.-J. (2002). Microbacterium aerolatum sp. nov., isolated from the air in the 'Virgilkapelle' in Vienna. Int J Syst Evol Microbiol 52, 1229-1234. 